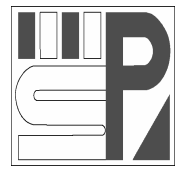

Science Press
Journal of Arid Land

2012, 4(1): 77-84

doi: 10.3724/SP.J.1227.2012.00077

jal.xjegi.com; www.chinasciencejournal.com

\title{
Range extension of four highland agamid lizards in Shimshal Pamir, Pakistan
}

\author{
Babar KHAN ${ }^{1,2 *}$, Waseem AHMED ${ }^{3}$, Abdukadir Ablimit $^{2}$, Shamim FAKHRI ${ }^{4}$, Hassan ALI ${ }^{1}$ \\ ${ }^{1}$ World Wide Fund for Nature Pakistan, Gilgit 15100, Pakistan; \\ ${ }^{2}$ Xinjiang Institute of Ecology and Geography, Chinese Academy of Sciences, Urumqi 830011, China; \\ ${ }^{3}$ Pakistan Wildlife Foundation, Islamabad, Pakistan; \\ ${ }^{4}$ Zoological Survey Department, Karachi, Pakistan
}

\begin{abstract}
As part of the Sino-Pak trans-boundary cooperation for conservation and sustainable development in Pamir border region, World Wild Fund (WWF)-Pakistan conducted a preliminary social, economic and ecological survey in the Shimshal-Pamir Lakes area in July 2009. The purpose of the study was to explore potentials and opportunities for future collaborative conservation of some species, habitats and high altitude ecosystems in the border region between China and Pakistan. The two-week herpetological study in the Shimshal Pamir area of Khunjerab National Park (KNP) along Pakistan-China border was an integral part of the survey, conducted exclusively to document reptilian fauna with a special emphasis on investigating their occurrence, distribution and status in the study area. Field investigations were performed during daytime when it was hot enough and reptiles were active, basking or feeding. A total of 15 specimens belonging to four species of the Agamidae family were captured by striking stones and beating bushes with sticks. Collected specimens were preserved using $10 \%$ formalin solution, tagged with field information and stored in Zoological Survey Department, Karachi for future reference. Laboratory investigations were carried out for pholidosic counts and morphometric measurements. A detailed review of relevant literature, habitat characteristics and laboratory investigations revealed the occurrence of Laudakia himalayana, $L$. pakistanica, L. tuberculata and $L$. badakhshana at 4,082 m, 4,172 m, 4,005 m and 4,240 m asl, respectively, which are much higher altitudes as compared to the previously reported heights of $3,353 \mathrm{~m}, 3,200 \mathrm{~m}, 2,500 \mathrm{~m}$ and 2,400 $\mathrm{m}$ asl. The terrain offers a variety of ecological barriers, in the form of fast and freezing running waters and massive glaciers with peculiar harsh climatic conditions prevailing for nine months of the year, which restricts species migration and thus increases endemism. Although one of the four species recorded from the study area, i.e. L. pakistanica is endemic to Pakistan, L. tuberculata and L. badakhshana are new records from Shimshal, Pakistan, so a detailed investigation is suggested for further herpetological records from the study area.
\end{abstract}

Keywords: Laudakia himalayana; L. pakistanica; L. tuberculat; L. badakhshana; Agamidae; Gilgit-Baltistan; Khunjerab National Park; Pakistan

Reptiles represent some of the oldest living species on the planet, having existed in many different forms for more than 230 million years. Although the evolution process has drastically altered their species number, there are still more than 7,500 forms of reptiles found throughout the world. Reptiles play a vital role in the proper functioning of the world's ecosystems, mostly being natural carnivores help eliminate a number of insects, crabs and other pests, which may damage crops and other food resources. Use of reptile skin to make leather goods and their centuries-old food and pet value make them significantly important for local economies.

Pakistan hosts a highly unique biodiversity due to huge environmental and altitudinal gradients, leading to complex zoogeographic patterns. This richness is particularly high for reptiles, with about 197 taxa including lizards, snakes, turtles, tortoise, crocodiles and 
gavels recorded (Rahman and Ifat, 1997). The family Agamidae contains two subfamilies, approximately 52 genera and more than 350 species (Khan and Mahmood, 2004). Despite the fact that $30 \%$ of the reptiles and amphibians are endemic to Pakistan (Khan 2006, 2008), the knowledge concerning herpetofauna of the country is still not complete (Minton, 1966; Borkin, 1999; Sindaco and Jerem; 2008, Xu et al., 2009). The genus Laudakia of Agamidae lizards is distributed throughout Pakistan with a counting of 13 species being reported, so far, from various parts of the country (Minton, 1966; Mertens, 1969; Baig, 1989; Khan, 2006). Seven Laudakia species have been recorded from the mountainous areas, including L. pakistanica (2,500-3,200 m), L. himalayana (3,000-3,200 m), L. caucasia (1,800-3,000 m), L. tuberculata $\left(1,500_{-}\right.$ 2,500 m), L. badakhshana (450-2,400 m), L. nupta $(1,800-2,000 \mathrm{~m})$, and $L$. fusca from $1,800 \mathrm{~m}$ asl (Baig, 2001; Khan, 2006; Ficetoal, 2010).

Gilgit-Baltistan, formerly called Northern Areas of Pakistan, falls at the boundary between the Paleartic and the Oriental zoogeographical realms (Duellman, 1999; Sindaco and Jerem, 2008), and it is the junction point of the world's three greatest mountain ranges: Himalayas, Karakoram and Hindu Kush (Khan et al., 2004). The Karakorum-Pamir mountain area, situated in the extreme north of Gilgit-Baltistan, is highly rugged, remote and challenging. So despite having biogeographically unique features, the area is poorly studied in biodiversity (Xu et al. 2009), particularly about herpetofauna. An exception researcher is Khan (2006), who conducted some studies on wildlife of Khunjerab National Park including Shimshal, and reported two Agamid species (L. himalayana and $L$. pakistanica) from the Shimshal village, $50 \mathrm{~km}$ short of Shimshal-Pamir Lake.

This study was conducted during July 2009 to investigate the occurrence, abundance, distribution and status of different reptilian species in the Shimshal-Pamir area of Khunjerab National Park (Pakistan) and recorded the occurrence of four Laudakia species never reported before, i.e. L. himalayana, L. pakistanica, L. tuberculata and L. badakhshana at a higher altitude $(3,200 \mathrm{~m}$ asl) near Pakistan-China border, which provides enough evidence for an extension of current distribution limit of the Agama lizards (genus Laudakia) further northward into the Karakorum mountain range.

\section{Materials and Methods}

\subsection{Study area}

The Gilgit-Baltistan region of Pakistan comprises an intricate system of mountain ranges, i.e. Himalayas, Hindu Kush and Karakoram, conjoining heads at Pamir Knot and giving birth to several valleys on their way both up and down stream the Indus River (Baig, 2001). Shimshal-Pamir is a part of Khunjerab National Park over $4,455.06 \mathrm{~km}^{2}$ area in the extreme north of Pakistan, along Pakistan-China border. It was designated by the Gilgit-Baltistan government in 1975 to protect Marco polo sheep Ovis ammon polii in its natural habitat (PGoGB, 2010). Starting right from Shimshal village, the study area extends some $50 \mathrm{~km}$ into the mountainous valley, covering different habitat types ranging from $3,078 \mathrm{~m}$ to $4,731 \mathrm{~m}$ asl at Shimshal-Pamir Lake, and then borders with China (Fig. 1). Shimshal-Pamir Lake, locally called Shuvorth, covers an area of $32 \mathrm{~km}^{2}$ at an elevation of $4,755 \mathrm{~m}$ asl in the extreme north of Pakistan. It is along the southern border of Xinjiang, China and is about $40 \mathrm{~km}$ to the northwest of Shimshal village. Sherlik is the last valley from Pakistan side, whereas Tagdumbash, Bazaar and Raskam are the three villages bordering Chinese side. The majority of the local population is Muslim.

Three major streams originate from Sherlik valley watersheds, flow down the Ferzon, Mustag and Obrang nullahs on Pakistani territory, and merge into one stream near Sherblock post before entering China. Ferzon nullah originates from Varow Shimshal pass glacier, which feeds the Shimshal Pamir lakes and also provides water to a number of seasonal and perennial streams, peats, lakes and agricultural fields on the other side of the border. Lakes, peat lands and streams on both sides of the Pakistan-China border provide important habitats, staging and breeding places to a number of migratory birds and water fowls.

Shimshal comprises of four main villages, i.e. Farmanabad, Aminabad, Khizerabad and proper Shimshal village, having a total population of 2,500 living in 300 households. People take an agro-pastoral life pattern, subsistence farming and livestock herding being their primary sources of livelihood. A small proportion of youth are engaged in seasonal tourism activities. 


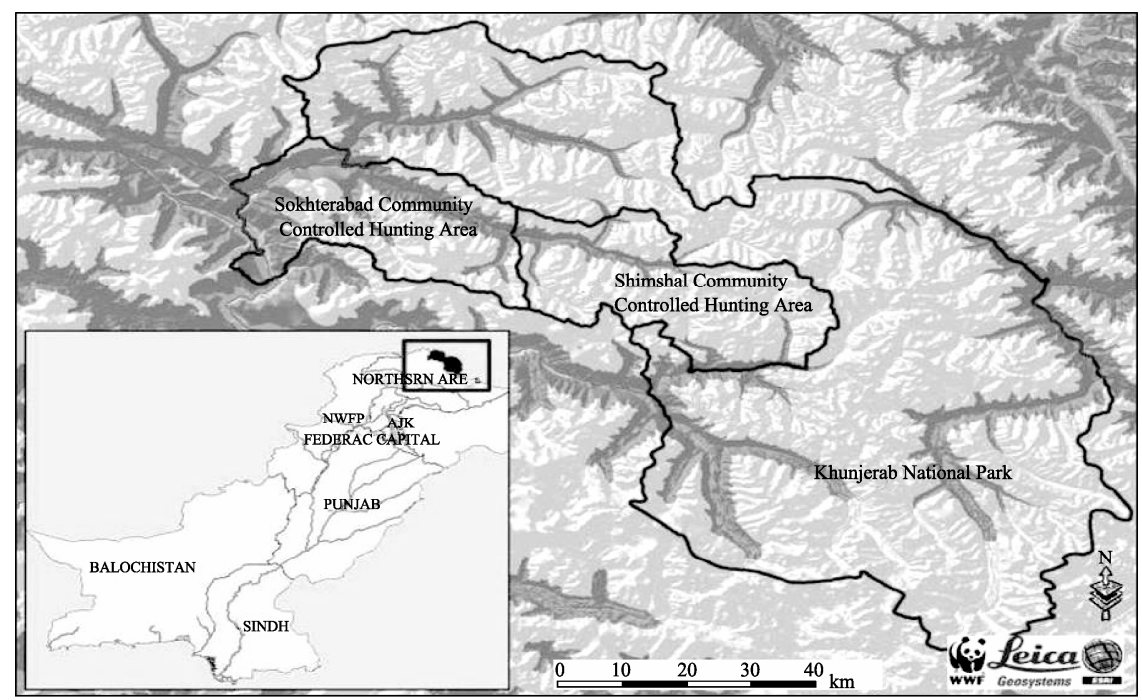

Fig. 1 Sketch of the study area

On average, the area receives $11 \mathrm{~mm}$ of rainfall monthly and western monsoon seldom crosses the high mountains of Karakorum Range, usually staying afar. Harsh climate prevails with severe cold winters below freezing temperature from October onward, but pleasant sunny days appear with temperature ascending up to $25^{\circ} \mathrm{C}$ after April till the peak summer season (IUCN, 2003).

\subsection{Experimental design}

Field investigations were carried out almost every day from 10:00-15:00 for reptiles particularly lizards, when it was hot enough and lizards were active, basking or feeding (Heyer et al., 1994). Lizards were located mostly by turning stones, looking at and through bushes, and walking along dry stream beds. A total of 15 specimens of fast moving agamid lizards including five L. himalayana, seven L. pakistanica, two L. tuberculata and one L. badakhshana were manually captured by striking stones and beating sage bushes with a stick. Some were also pulled out of crevices, holes and from beneath the rocks and bushes using long metal forceps. Collected specimens were killed and preserved by injecting $10 \%$ formalin solution into belly, neck, legs and tail. Each specimen was tagged with necessary field information and preserved in the Zoological Survey Department, Karachi for future study, reference and record (Khan, 2006; Baig, 2008).

\subsection{Lab investigation}

During laboratory examination, pholidosic counts and measurements (in millimeter) were made for the number of upper labials, the number of lower labials, and the number of supra-ocular scales, callose pre-anal and callose abdominal scales. The number of scales around mid body, snout-vent length and caudal length were also recorded in millimeters for necessary morphometric investigation (Göcmen et al., 2003; Baig, 2008). The specimens were identified with the help of most recent keys available in literature (Khan, 2002, 2006, 2008).

\section{Results}

\subsection{Habitat description}

The study area offers a range of habitat types, starting from moderately plain green patches near Shimshal village to gentle slopes abound in small bushes and shrubs, dry and barren mountains, alpine meadows and snow capped peaks (Fig. 2). Slopes are covered by shrubs like Hippophia, Aphidra and Artimisia species, whereas the dry river and stream beds have Myricaria germanica, Aerva lanata, Artemisia brevifolium, Corydalis adiantifolius and Potentilla drydanthoidas, which offer comparatively better habitat conditions to Agamid lizards, particularly to L. himalayana and $L$. pakistanica. The swift rocky stream running all along the trek up to the Shimshal Pamir Lake (4,731 m) exhibits absolutely undulating terrain with scarce and scattered species of Aerva lanata, Artemisia brevifolium and Astragalus spp. that provide suitable habitats to L. pakistanica, L. tuberculata and L. badakhshana (Fig. 3). 


\subsection{Species observed}

A total of 15 specimens belonging to four species of the genus Laudakia of family Agamidae were recorded from the study area (Table 1). The pholidosic measurements of collected specimens were made (Table 2) and specimen information was compared with previously described specimens in literature (Minton, 1966; Khan, 2006).

\subsection{New distribution records}

Thirteen species of genus Laudakia are distributed throughout Pakistan (Khan, 2006). The species found at high altitudes include: Laudakia pakistaninca (2,500-3,200 m), Laudakia himalayana (3,000-3,200 $\mathrm{m})$, Laudakia caucasia (1,800-3,000 m), Laudakia tuberculata (1,500-2,500 m), Laudakia badakhshana (450-2,400 m), Laudakia nupta (1,800-2,000 m) and Laudakia fusca (up to $1,800 \mathrm{~m}$ ) (Khan, 2006). The species belonging to the genus Laudakia had never been reported beyond 3,200 $\mathrm{m}$ asl. Only two agamids, L. himalayana and L. pakistanica, were reported earlier from KNP (Khan, 2006). During the present study, one specimen of L. himalayana was captured at 4,082 $\mathrm{m}$, two specimens of $L$. pakistaninca at $4,172 \mathrm{~m}$, one of L. tuberculata at 4,005 $\mathrm{m}$ and one of L. badakhshana at 4,240 $\mathrm{m}$ asl. Hence the occurrence of $L$. $t u$ berculata and L. badakhshana in Shimshal Pamir extends their distribution further into Karakorum mountain range at much higher altitudes than previously reported (Khan, 2006).

\subsection{Features of four species}

2.4.1 Laudakia himalayana, Steindachner, 1869

(1) Morphology

Five specimens of Laudakia himalayana were collected from the study area (Table 1). This species was earlier reported from Qarchenai, Dhee and Shimshal valleys of KNP between 3,048-3,353 m asl (Khan, 2006), Gilgit and Chitral between 3,000-3200 $\mathrm{m}$ asl (Khan, 2004). It is a diurnal herbivore that breeds during May-June, and juveniles are seen from July to August. During the period of this study, mixed gatherings of adults and juveniles were observed. They feature grayish dorsal color, with light spots; their heads and necks have small spinose scales, and tails dorso-ventrally flattened at base become round and taper at tip (Fig. 4).

(2) Status

The species abounds on rocks at seasonal stream beds and along stream banks near Shimshal village at 3,090 $\mathrm{m}$, up to 4,082 $\mathrm{m}$ asl near Arbab Purrein along the trek towards Shimshal Lake.

(3) Range

Laudakia himalayana is distributed from western Himalayas to Tajikistan. In Pakistan, the species has been recorded from northern areas around Gilgit and Chitral (Khan, 2006). Khan (2006) recorded it from Qarchenai, Dhee and Shimshal valleys and also from Aagh, Zoi Saam, Toghraqeen, Padekishk and Arbab Kook nullahs at different elevations from 3,000 to $4,000 \mathrm{~m}$ in Karakorum mountain range. This study

Table 1 Field records of collected specimens from the study area

\begin{tabular}{|c|c|c|c|c|c|}
\hline No. & Species & Tag number & Sex & Location & Elevation $(\mathrm{m})$ \\
\hline 1 & Laudakia himalayana & SM-PM 2009-3 & $\mathrm{M}$ & $36^{\circ} 26^{\prime} 27.6^{\prime \prime} \mathrm{N} 75^{\circ} 20^{\prime} 01.2^{\prime \prime} \mathrm{E}$ & 3,090 \\
\hline 2 & Laudakia himalayana & SH-PM 2009-4 & M & $36^{\circ} 26^{\prime} 27.6^{\prime \prime} \mathrm{N} 75^{\circ} 20^{\prime} 01.2^{\prime \prime} \mathrm{E}$ & 3,090 \\
\hline 3 & Laudakia himalayana & SH-PM 2009-5 & M & $36^{\circ} 27^{\prime} 40.2^{\prime \prime} \mathrm{N} 75^{\circ} 26^{\prime} 47.0^{\prime \prime} \mathrm{E}$ & 3,486 \\
\hline 4 & Laudakia himalayana & SH-PM 2009-6 & $\mathrm{F}$ & $36^{\circ} 27^{\prime} 51.9^{\prime \prime} \mathrm{N} 75^{\circ} 28^{\prime} 06.1^{\prime \prime} \mathrm{E}$ & 3,703 \\
\hline 5 & Laudakia himalayana & SH-PM 2009-10 & $\mathrm{F}$ & $36^{\circ} 28^{\prime} 10.4^{\prime \prime} \mathrm{N} 75^{\circ} 29^{\prime} 28.2^{\prime \prime} \mathrm{E}$ & 4,082 \\
\hline 6 & Laudakia pakistanica & SM-PM 2009-1 & M & $36^{\circ} 26^{\prime} 27.6^{\prime \prime} \mathrm{N} 75^{\circ} 20^{\prime} 01.2^{\prime \prime} \mathrm{E}$ & 3,090 \\
\hline 7 & Laudakia pakistanica & SH-PM 2009-2 & M & $36^{\circ} 26^{\prime} 27.6^{\prime \prime} \mathrm{N} 75^{\circ} 20^{\prime} 01.2^{\prime \prime} \mathrm{E}$ & 3,090 \\
\hline 8 & Laudakia pakistanica & SH-PM 2009-7 & M & $36^{\circ} 27^{\prime} 40.2^{\prime \prime} \mathrm{N} 75^{\circ} 26^{\prime} 47.0^{\prime \prime} \mathrm{E}$ & 3,486 \\
\hline 9 & Laudakia pakistanica & SH-PM 2009-8 & $\mathrm{F}$ & $36^{\circ} 27^{\prime} 51.9^{\prime \prime} \mathrm{N} 75^{\circ} 28^{\prime} 06.1^{\prime \prime} \mathrm{E}$ & 3,703 \\
\hline 10 & Laudakia pakistanica & SH-PM 2009-9 & $\mathrm{F}$ & $36^{\circ} 28^{\prime} 10.4^{\prime \prime} \mathrm{N} 75^{\circ} 29^{\prime} 28.2^{\prime \prime} \mathrm{E}$ & 4,082 \\
\hline 11 & Laudakia pakistanica & SH-PM 2009-13 & M & $36^{\circ} 28^{\prime} 19.7^{\prime \prime} \mathrm{N} 75^{\circ} 34^{\prime} 53.2^{\prime \prime} \mathrm{E}$ & 4,172 \\
\hline 12 & Laudakia pakistanica & SH-PM 2009-14 & $\mathrm{F}$ & $36^{\circ} 28^{\prime} 19.7^{\prime \prime} \mathrm{N} 75^{\circ} 34^{\prime} 53.2^{\prime \prime} \mathrm{E}$ & 4,172 \\
\hline 13 & Laudakia tuberculata & SM-PM 2009-11 & M & $36^{\circ} 28^{\prime} 25.5^{\prime \prime} \mathrm{N} 75^{\circ} 33^{\prime} 21.0^{\prime \prime} \mathrm{E}$ & 4,005 \\
\hline 14 & Laudakia tuberculata & SH-PM 2009-12 & M & $36^{\circ} 28^{\prime} 23.2^{\prime \prime} \mathrm{N} 75^{\circ} 33^{\prime} 07.1^{\prime \prime} \mathrm{E}$ & 3,942 \\
\hline 15 & Laudakia badakhshana & SM-PM 2009-15 & M & $36^{\circ} 28^{\prime} 04.1^{\prime \prime} \mathrm{N} 75^{\circ} 35^{\prime} 44.4^{\prime \prime} \mathrm{E}$ & 4,240 \\
\hline
\end{tabular}


result shows that its distribution range extends further north in the country at 4,082 $\mathrm{m}$ asl in Shimshal valley in Gilgit-Baltistan (Fig. 8).

2.4.2 Laudakia pakistanica auffenbergi, Baig and Bohme, 1996

(1) Morphology

Seven specimens of Laudakia pakistanica were collected (Table 1). Although this species is restricted to 2,438 $\mathrm{m}$ in the Himalayas (Baig, 2001), it was surprisingly seen above 3,090-4,172 $\mathrm{m}$ in Shimshal area of Karakorum mountain range. Ludakia pakistanica is endemic to Pakistan with three sub-species: L. pakistanica pakistanica, L. p. auffenbergi and L. p. khani, of which $L$. $p$. auffenbergi had previously been recorded from the study area. Most of the specimens collected were found in pairs, possibly because of breeding season. Their heads have smooth scales, and flanks are with spinose scales. Dorsal body color is brownish gray, with white spots arranged in longitudinal rows. Male is slightly larger than female and bear a distinct patch of spinose scales on flanks and orange colored spinose scales behind ear opening. Usually the lizards are observed either basking in sun or running after each other (Fig. 5).

(2) Status

The species is common on rocks in the study area, along streams near Shimshal village at 3,090 m, up to 4,172 m asl near Arbab Purein trek.

(3) Range

Laudakia pakistanica is widely distributed in northern Pakistan around Gilgit, Mansehra and northeastern Pakistan (Baig, 2001). Prior to the present study, the highest distribution records for L. pakistanica were 2,438 $\mathrm{m}$ asl from Besham, district Swat, North West Frontier Province (NWFP) (Baig, 2001), but this study result shows that its distribution range extends further north in the country up to $4,172 \mathrm{~m}$ asl with recording in Shimshal valley of KNP (Fig. 9).
2.4.3 Laudakia tuberculata, Hardwicke and Gray, 1827 (1) Morphology

Posterior sides of head and neck bear small spinose scales extending on flanks. Male is differentiated from female due to the presence of callose pre-anal and callose abdominal scales. In adult males, head is pale, throat and chest are bluish and ventral side of the body is white in color (Fig. 6). The specimens were collected from under stones. Scale counts and measurements of different body parts of the collected specimens are given in Table 2.

(2) Status

The species is common in the western Himalayas, not previously seen above $2,500 \mathrm{~m}$ asl (Khan, 2006) but two specimens were found at 3,942 and 4,005 $\mathrm{m}$ asl near Parien Sar in Shimshal valley.

(3) Range

Laudakia tuberculata was reported earlier from eastern Afghanistan, northern parts of Pakistan, Kashmir and Nepal at an elevation range between 1,500-2,500 $\mathrm{m}$ asl (Ananjeva and Tuniev, 1994; Khan, 2006). This study confirms its occurrence up to $4,000 \mathrm{~m}$ asl, extending its north-west range and making it one of the widely ranging agamids in northern areas of Pakistan (Fig. 10).

2.4.4 Laudakia badakhshana, Anderson and Leviton, 1969

(1) Morphology

They are dorsally olive gray, ventrally grayish white and have tails with dark cross bars. Their scales on thighs are large and keeled and a large patch of callose abdominal scales are present (Fig. 7). Scale counts and measurements of different body parts of the collected specimens are given in Table 2 .

(2) Status

The species is not so common in the study area. A single specimen was collected from Shujerab along the

Table 2 Pholidosis and measurements of specimens of Landakia

\begin{tabular}{ccccccc}
\hline No. & Species & SL $(\mathrm{mm})$ & IL $(\mathrm{mm})$ & SVL $(\mathrm{mm})$ & CL $(\mathrm{mm})$ & SATB \\
\hline 1 & Laudakia himalayana & $10-11$ & $9-10$ & $98-104$ & $130-141$ & $36-39$ \\
2 & Laudakia pakistanica & $12-13$ & $11-12$ & $118-124$ & $121-132$ \\
3 & Laudakia tuberculata & 12 & 11 & $147-149$ & $153-157$ & $31-33$ \\
4 & Laudakia badakhshana & 12 & 10 & 102 & Broken & 31 \\
\hline
\end{tabular}

Note: $\mathrm{SL}=$ Supra labial, $\mathrm{IL}=$ Infra labial, $\mathrm{SVL}=$ Snout-vent length, $\mathrm{CL}=$ Caudal length, $\mathrm{SATB}=$ Scales around tail base, $\mathrm{DSR}=$ Dorsal scale rows. 


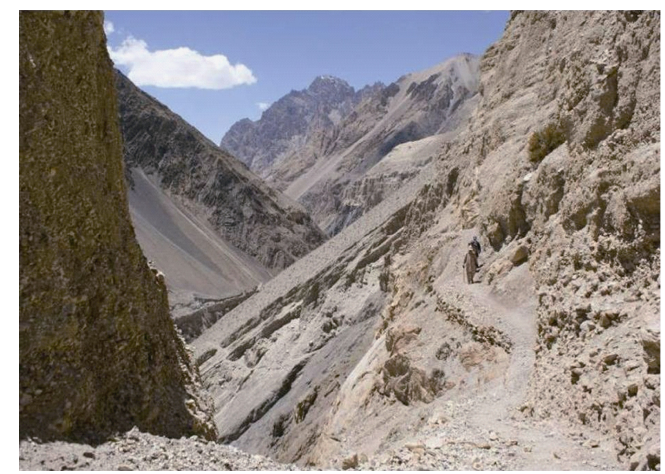

Fig. 2 Habitat in middle of the Shimshal valley, KNP

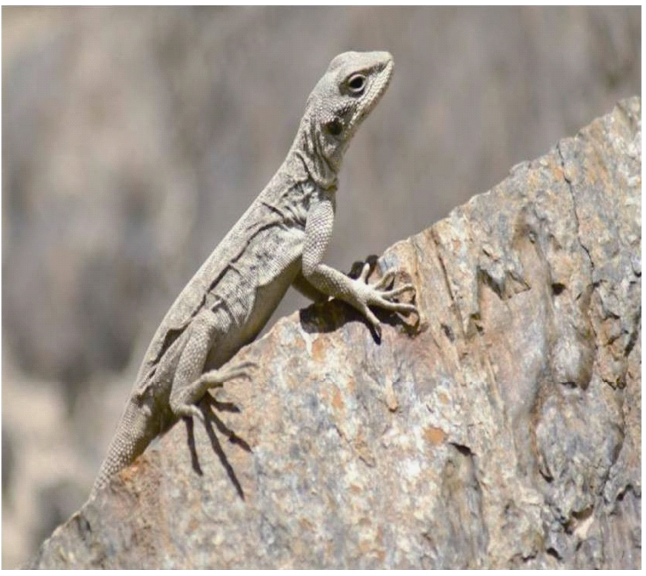

Fig. 4 Laudakia himalayana

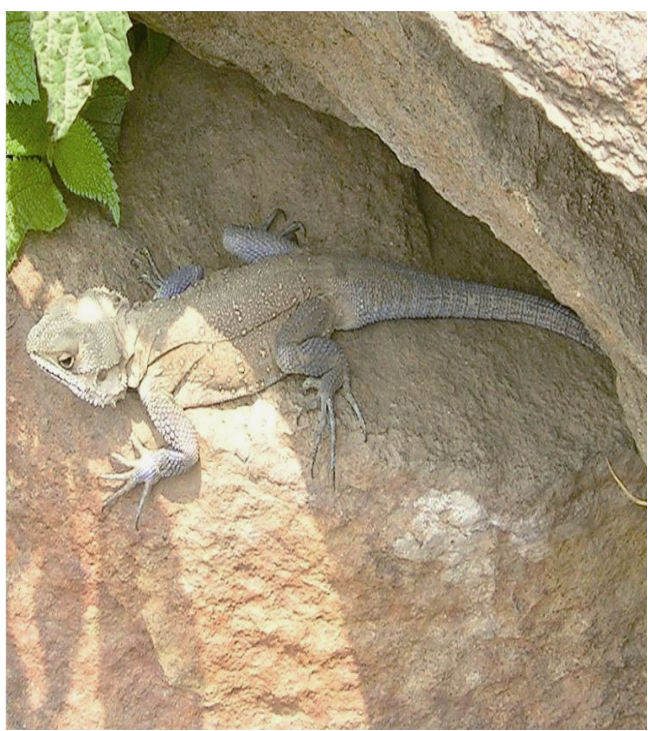

Fig. 6 Laudakia tuberculata

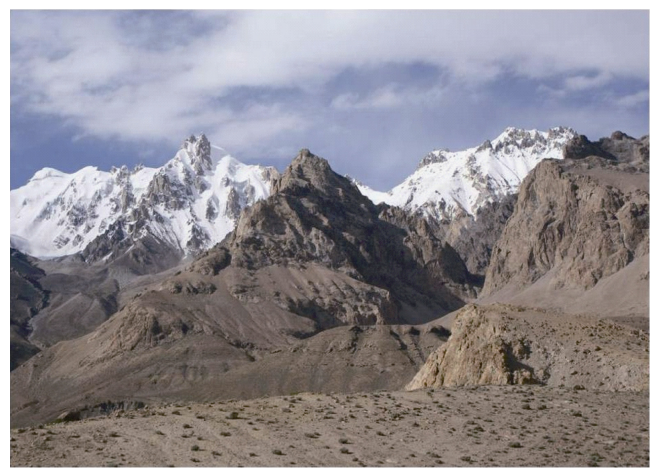

Fig. 3 Habitat at high altitudes near Shimshal Pamir Lake in Shimshal valley, KNP

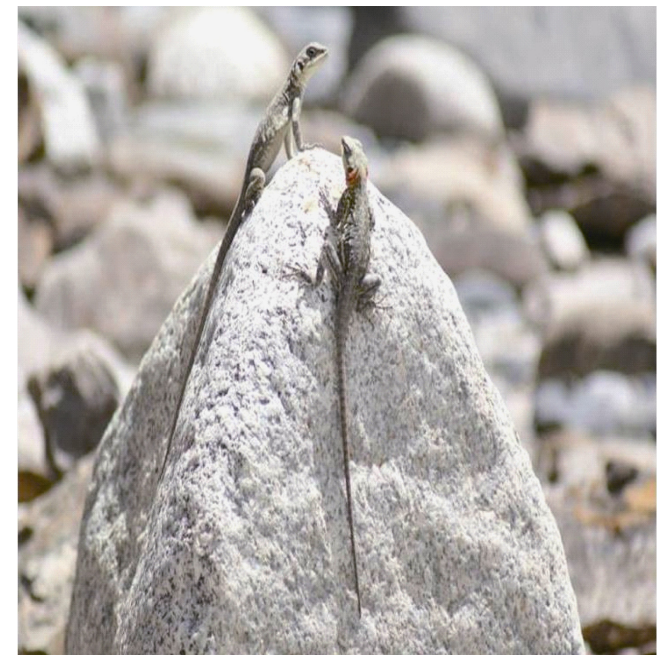

Fig. 5 Laudakia pakistanica

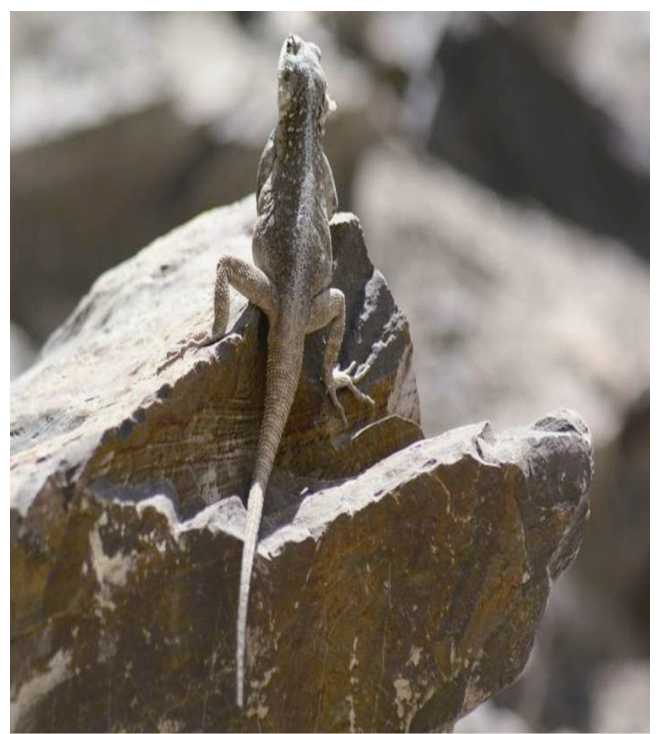

Fig. 7 Laudakia badakhshana 
trek to Shimshal Lake.

(3) Range

The species was reported earlier from Afghanistan, India and China (Baig, 2001) and from KNP in Pakistan (Khan, 2006). However, this study result shows that its distribution range extends further north in the country to Shimshal Pamir at 4,240 m asl (Fig. 11).

\section{Discussion and conclusion}

Amongst the four recorded species, L. himalayana and L. pakistanica were previously reported from KNP, while the species $L$. tuberculata and L. badakhshana are new records from the study area. Pholidisic counts and morphometric measurements of the collected specimens show that most of the studied characters fall within the range given by Khan (2006) except

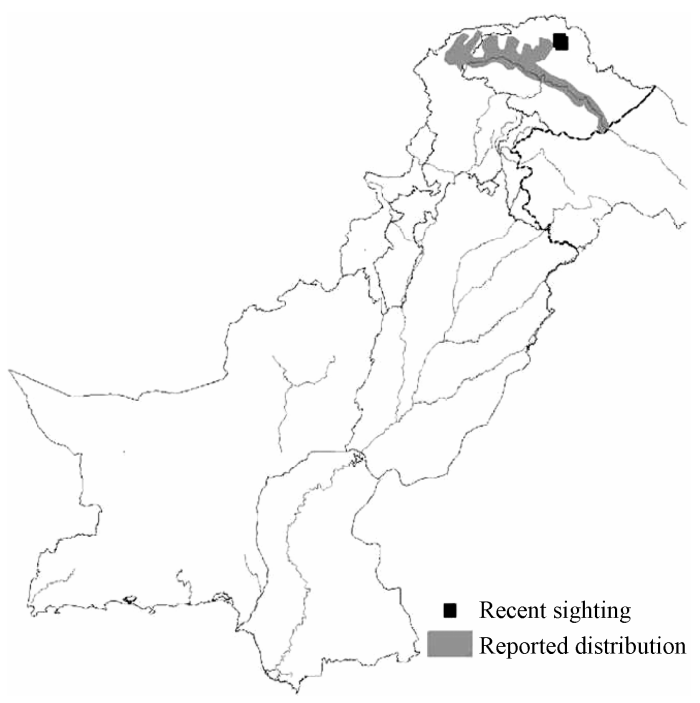

Fig. 8 Distribution of Laudakia himalayana

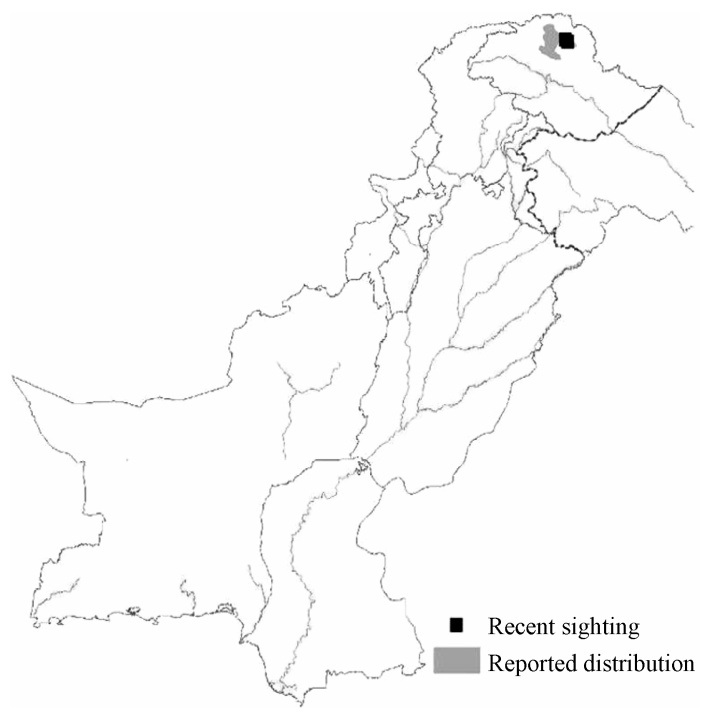

Fig. 10 Distribution of Laudakia tuberculata those of L. badakhshana whose scales at tail base (SATB) are 31 rather than Khan's 19-25. Pholidisic counts and measurements for the recent specimens also show slight differences from the report of Minton (1966).

Since most of the study area is above $4,000 \mathrm{~m}$ asl where mean minimum temperature stays below $0^{\circ} \mathrm{C}$ during October-April, existence of cold blooded species like amphibians and reptiles can be a challenge (Baig, 2001). The study area surrounding Shimshal Pamir Lake remains snow bound for as long as nine months (September-May) and that is why not a single water dependent species such as frog, turtle and toad was seen there, except the agamids, which often regulate their body temperature by basking in the sun on sun-warmed rocks.

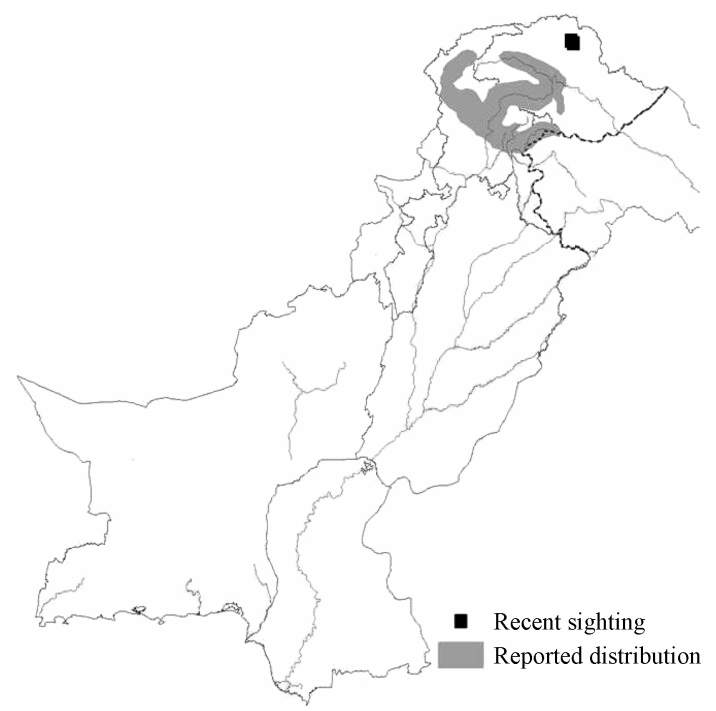

Fig. 9 Distribution of Laudakia pakistanica

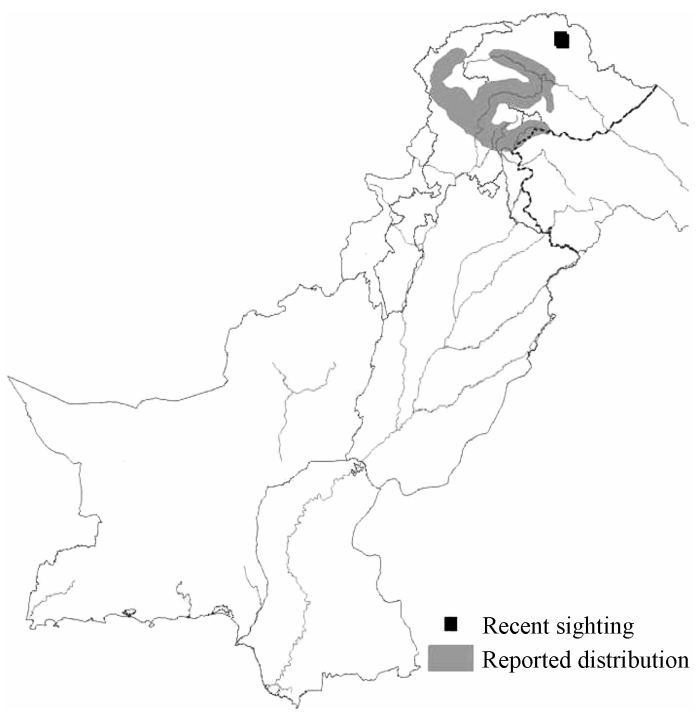

Fig. 11 Distribution of Laudakia badakhshana 
The terrain offers such ecologically isolating barriers as fast and freezing running waters and massive glaciers. Peculiar harsh climate prevails for most of the year, naturally restricting movement of species and increasing endemism. L. pakistanica comes as a good proof.

Prior to this study, all the four species were seen in habitats below $3,353 \mathrm{~m}$ asl (Khan, 2006), but recording them in Shimshal Pamir Lake area between 3,353 and 4,240 $\mathrm{m}$ asl extends their distribution range further north in the Gilgit-Baltistan region of Pakistan. Since two out of the four species, i.e. L. tuberculata and $L$. badakhshana are new records from the study

\section{References}

Ananjeva N B, Tuniev. 1994. Some aspects of historical biogeography of Asian rock agamids. Russian Journal of Herpetology, 1(1): 43-49.

Baig K J. 1989. A new species of Agama (Sauria, Agamidae) from northern Pakistan. Bulletin of the Kitakyushu Museum of Natural History \& Human, 9: 117-122.

Baig K J. 1992. Systematic studies of the Stellio group of Agama (Sauria: Agamidae). Ph.D Thesis. Quaid-e-Azam University, Islamabad.

Baig K J. 2001. Annotated checklist of amphibians and reptiles of the northern mountain region and Potwar plateau of Pakistan. Proceedings of the Pakistan Academy of Sciences, 38(2): 121-130.

Baig K J. 2008. Detailed Ecological Assessment of Kheenjar Lake, Sindh. Lahore: WWF-Pakistan, 27-29.

Borkin L J. 1999. Distribution of amphibians in North Africa, Europe, Western Asia, and the Former Soviet Union. In: Duellman W E. Patterns of Distribution of Amphibians. Baltimore: Johns Hopkins University Press, 329-420.

Ficetola G F, Crottini A, Casiraghi M, et al. 2010. New data on amphibians and reptiles of the Northern Areas of Pakistan: distribution, genetic variability and conservation issues. North-Western Journal of Zoology, 6 (1): 1-12.

PGoGB. 2010. Re-notification of the boundaries of Khunjerab National Park, Hunza-Nagar. F\&A-8 (4)/F/2001. Forest, Wildlife \& Environment, Provincial Government of Gilgit-Baltistan, Gilgit, 1-12.

Göcmen B, Tosunoglu M, Tskavak E. 2003. A taxanomic comparision of the Hardan, Laudakia stellio (Reptilia, Agamidae), populations of southern Turkey (Hatay) and Cyprus. Zoology in the Middle East, 28: $25-32$.

Heyer W R, Donnelly M A, Mcdiarmid R W, et al. 1994. Measuring and monitoring biological diversity: standard methods for amphibians. Washington: Smithsonian Institution Press.

IUCN Pakistan. 2003. State of the Environment and Development in Northern Areas. Karachi: IUCN Pakistan, 38-50.

Jane M, Hale J, Mantziou G, et al. 2009. Historical biogeography, phylogenetic relationships and intraspecific diversity of agamid liz- area, a detailed herpetological investigation is suggested for the future.

\section{Acknowledgements}

The authors thank the WWF Netherlands for funding the study through Saving Wetlands Sky High programme, and WWFPakistan for facilitation. Field staffs of Khunjerab National Park and Gilgit-Baltistan Forest \& Wildlife Department are also thanked for their cooperation and administrative support. Local communities of KNP, especially the Shimshalies (people of Shimshal valley), are appreciated and sincerely acknowledged for their hospitality, devotion and help throughout the study. Many thanks are also due to M Sharif KHAN and JAL editors for rigorously improving the manuscript.

ards in the Central Asian deserts of Kazakhstan and Uzbekistan. Molecular Phylogenetics and Evolution, 53: 99-112.

Khan A A. 1996. Management Plan of Khunjerab National Park. Lahore: WWF-Pakistan.

Khan B, Khattak R A, Khattak R A. 2004. Physico-chemical characterizations and fertility evaluation of Gilgit soils. Journal of Agricultural Research, 42(3-4): 305-312.

Khan M S. 1994. Key for identification of amphibians and reptiles of Pakistan. Pakistan Journal of Zoology, 26(3): 225-249.

Khan M S. 2000. Amphibians and Reptiles of Pakistan (in Urdu). Lahore: Urdu Science Board, 138.

Khan M S. 2000. Key and checklist to the Lizards of Pakistan. Herpetozoa, 15: 179-199.

Khan M S. 2004. Checklist and key to the Lizards of Pakistan. Pakistan Journal of Zoology, 5(Suppl.): 1-25.

Khan M S. 2006. Amphibians and reptiles of Pakistan. Florida: Krieger Publishing Company, 32950: 311-318.

Khan, M S. 2008. Amphibians of Pakistan. Reptilia, 60: 61-66.

Khan M Z, Mahmood N. 2004. Study of population status and natural history of Agamid lizards of Karachi. Pakistan Journal of Biological Sciences, 7(11): 1942-1945.

Khan W A. 2006. Wildlife Survey of Khunjerab National Park, Northern Areas, Pakistan. Lahore: WWF-Pakistan, 39- 40.

Martens R. 1969. Die Amphibian and Reptilian West Pakistan. Stuttgarter Beiter Z. Naturkunde, No. 197.

Minton S A. 1966. A contribution to the Herpetology of West Pakistan. Bulletin of the American Museum of Natural History, 134: 27-184.

Rahman H, Ifat F. 1997. A revised checklist of Reptiles of Pakistan. Records Zoological Survey of Pakistan, 8: 1-17.

Sindaco R, Jerem-enko V K. 2008. The Reptiles of the Western Palearctic. 1, Belvedere, Latina.

$\mathrm{Xu}$ J, Grumbine R E, Shrestha A, et al. 2009. The melting Himalayas: cascading effects of climate change on water, biodiversity, and livelihoods. Conservation Biology, 23: 520-530. 